\title{
DOES AVIAN GUT PASSAGE FAVOUR SEED GERMINATION OF WOODY SPECIES OF THE CHACO SERRANO WOODLAND IN ARGENTINA?
}

\begin{tabular}{|r|l|}
\hline Journal: & Botany \\
\hline Manuscript ID & cjb-2016-0243.R1 \\
\hline Manuscript Type: & Article \\
\hline Date Submitted by the Author: & $21-$ Nov-2016 \\
\hline Complete List of Authors: & $\begin{array}{l}\text { Díaz Vélez, María Celeste; Instituto Multidisciplinario de Biologia Vegetal, } \\
\text { Ferreras, Ana Elisa; Instituto Multidisciplinario de Biologia Vegetal } \\
\text { Silva, Wesley; Universidade Estadual de Campinas, biologia animal } \\
\text { Galetto, Leonardo; Instituto Multidisciplinario de Biologia Vegetal, }\end{array}$ \\
\hline Keyword: & $\begin{array}{l}\text { avian gut passage, deinhibition, germination, scarification, native woody } \\
\text { species }\end{array}$ \\
\hline &
\end{tabular}

\section{SCHOLARONE \\ Manuscripts}




\section{DOES AVIAN GUT PASSAGE FAVOUR SEED GERMINATION OF WOODY SPECIES OF THE CHACO SERRANO WOODLAND IN ARGENTINA?}

María Celeste Díaz Vélez ${ }^{1}$, Ana Elisa Ferreras ${ }^{1}$, Wesley Rodrigues Silva ${ }^{2}$ and Leonardo

\section{Galetto $^{1,3}$}

${ }^{1}$ Instituto Multidisciplinario de Biología Vegetal (IMBIV-CONICET), Universidad Nacional de Córdoba, Av. Vélez Sársfield 1611, C.C. 495, 5000, Córdoba, Argentina. e-mail: anitaferreras@gmail.com

${ }^{2}$ Laboratory of Vertebrate-Plant Interactions, Department of Animal Biology, Campinas State University, Campinas, Brazil.e-mail: wesley@unicamp.br

${ }^{3}$ Facultad de Ciencias Exactas Físicas y Naturales, Universidad Nacional de Córdoba, Av. Vélez Sársfield 299, X5000JJC, Córdoba, Argentina.e-mail:leo@imbiv.unc.edu.ar Corresponding author: M. Celeste Díaz Vélez, Instituto Multidisciplinario de Biología Vegetal (IMBIV-CONICET), Universidad Nacional de Córdoba, Av. VélezSársfield 1611, C.C. 495, 5000, Córdoba, Argentina; TE: 00-54-351-4331056; e-mail: celestemcbiol@ gmail.com 


\begin{abstract}
Frugivorous birds are key dispersal agents of many plant species and also may facilitate seed germination after gut-passage. However, the general effects of gut-passage on seed germination are still not clear, with positive, negative and neutral effects reported on seed germination. We evaluated seed germination of seven bird-dispersed plant species of the Chaco Serrano Woodland in Córdoba, Argentina: Celtis ehrenbergiana, Condalia spp., Lantana camara, Lithraea molleoides, Lycium cestroides, Schinus fasciculatus and Zanthoxylum coco. We compared germination percentages and germination speed among seeds ingested by birds, manually extracted seeds, and seeds from intact fruits in order to understand which mechanisms are acting on bird gut-passed seeds. For six plant species, the action of frugivorous birds increased seed germination percentages and provides faster germination, either through scarification, deinhibition, or through combined mechanisms. Our results contribute to better understand the mechanisms acting on bird gutpassed seeds. Also, we show the pivotal role that frugivorous birds exert on the seed germination of native woody plant species in the threatened ecosystem of Chaco Serrano Woodland.
\end{abstract}

Keywords: avian gut passage, deinhibition, germination, scarification, native woody species 


\section{Introduction}

The consequences of avian fruit consumption on seed germination are important for assessing the effectiveness of frugivores in plant establishment and regeneration (Traveset 1998; Traveset et al. 2007; Schupp et al. 2010). The overall effects of gut-passage on seed germination are not consistent, with positive, negative and neutral effects on seed germination all reported (Traveset 1998; Traveset et al. 2007). The results of the interaction seems to be highly dependent on the plant and bird species interacting and on the methodology used in the testing (Robertson et al. 2006).

In bird-dispersed species, facilitation of seed germination may occur through different mechanisms; among those, two of the most important are deinhibition and scarification (Traveset 1998; Traveset and Verdú 2002; Robertson et al. 2006; Traveset et al. 2007). The deinhibition effect implies that through avian fruit ingestion, germination is increased only by separating seeds from the fruit pulp. This effect could occur even if seeds are regurgitated. The fruit pulp may contain germination inhibitors such as lipids, glycoalkaloids, coumarin, and various light-blocking pigments (Cipollini and Levey 1997; Samuels and Levey 2005; Traveset et al. 2007). In addition, high sugar content in fruit pulp may provoke high osmotic pressure (Traveset 1998; Samuels and Levey 2005), or it can be a source of infections by fungi or other pathogens affecting seed viability and germination (Traveset 1998; Samuels and Levey 2005). The scarification effect (chemical or mechanical) on germination involves modifications of the seed coat (Traveset 1998; Traveset and Verdú 2002; Samuels and Levey 2005; Robertson et al. 2006; Traveset et al. 2007; Traveset et al. 2008). The magnitude of the scarification effect depends on the characteristics of the frugivore species (length of the digestive tract, presence of a gizzard, seed retention time) as well as fruit and seed traits of each plant species (pulp composition, seed age, seed size, coat thickness and texture) (Traveset et al. 2007).

Most studies that evaluated effects of avian fruit consumption on seed germination tested the combined effects of scarification and the deinhibition effects without separating the two effects (Traveset and Verdú 2002; Samuels and Levey 2005). Samuels and Levey (2005) reviewed the literature and found that only $18 \%$ of the studies evaluating the effect of gut- 
passage on germination included comparisons that allowed the distinction between the scarification and the deinhibition effects to be made (this requires a comparison of seeds from intact fruits, manually extracted seeds, and gut-passed seeds). The recognition of the two components of germination stimulation has clarified greatly what is required to improve our knowledge on the role of frugivorous birds as seed dispersers in natural environments. Several of the previous studies suggested that pulp removal alone by frugivorous birds would be sufficient to increase seed germination, without evidence of a scarification effect (Izhaki and Safriel 1990; Barnea et al. 1991; Reid and Armesto 2010; Lehouck et al. 2011). On the other hand, a review from Traveset and Verdú (2002) showed that avian gut-passed seeds increase their germination percentages compared with manually extracted seeds, suggesting a high importance of the scarification effect. Moreover, Robertson et al. (2006) showed that deinhibition studies are prone to artefacts of the testing environment where whole fruits are tested in Petri dishes which prevent the washing away of inhibitors that would happen naturally in field conditions on soil. Thus the importance of the deinhibition effect may have been overestimated as a result of using an inappropriate method.

The Chaco subtropical forest of Argentina became a priority for biodiversity conservation because it is a threatened ecosystem that has suffered a strong increase in the rate of deforestation and habitat fragmentation due to the expansion of agriculture and urbanization (Gavier and Bucher 2004; Zak et al. 2004; Galetto et al. 2007; Aide et al. 2012), and suffered the proliferation of invasive exotic plant species (Giorgis et al. 2011). There are many species of woody plants, shrubs, grasses and vines in this ecosystem that are consumed and dispersed by frugivorous birds (Ponce et al. 2012; Díaz Vélez 2013). Birds are the only volant frugivores (no frugivorous bats exist in the area), and they may play an important role in maintaining bird-dispersed plant populations, not only by promoting seed movement, but also by increasing the likelihood or speed of seed germination. However, only a few studies have examined seed germination of Chaco bird-dispersed species (Funes et al. 2009; Grilli et al. 2009; Ashworth and Martí 2011), and even fewer studies have evaluated the different mechanisms that could facilitate seed germination (Renison et al. 2010). In this work, we want to answer two main questions: Does avian gut passage have a positive, a negative or a 
neutral effect on seed germination of native woody plant species? If it has a positive effect: Is this facilitation occurring through deinhibition, scarification or both?

\section{Methods}

Study site

The study was performed in the Chaco Serrano Woodland of Córdoba, Argentina. Mean annual temperature is $17.5^{\circ} \mathrm{C}$. Most precipitation falls from October to March (on average 750 mm per season, Luti et al. 1979; Moglia and Gimenez 1998) coinciding with the fruiting peak of bird-dispersed plants. The dry season extends from April to September (on average $116 \mathrm{~mm}$ per season), which coincides with the period of low temperatures (Capitanelli 1979).

The Chaco vegetation at the study site is highly fragmented due to recent agricultural and urban expansion (Zak et al. 2004). Fruits were collected from eight fragments $\left(31^{\circ} 09^{\prime} \mathrm{S}\right.$ to $31^{\circ} 13^{\prime} \mathrm{S}$ and $64^{\circ} 13^{\prime} \mathrm{W}$ to $64^{\circ} 17^{\prime} \mathrm{W}$ ) which are composed of secondary forest with a canopy that usually reaches 7-9 m high. Native vegetation includes numerous bird-dispersed species, the majority of which are trees and shrubs, with some climbers (such as Passiflora morifolia, P. suberosa) and many herbs (such as Salpichroa origanifolia, Solanum chenopodioides, Rivina humilis, Lantana grisebachii) (Cagnolo et al. 2006; Ponce et al. 2012; Díaz Vélez 2013).

Species studied

We collected fruits of seven native bird-dispersed woody species that are commonly eaten by birds and that were the most abundant in a bird-dispersed seed rain experiment performed within the study area (Díaz Vélez 2013). The characteristics of the plant and frugivorous bird species that consume their fruits are listed in Table 1.

\section{Seed treatments and germination experiments}

In order to understand which mechanisms are acting on bird gut-passed seeds, the scheme proposed by Samuels and Levey (2005) was used to compare germination percentages among seeds ingested by birds, manually extracted seeds, and seeds from intact fruits (Fig. 1). The three seed treatments were: 
a) Gut-passed seeds (G): seeds that were defecated and/or regurgitated by birds. If this treatment determines an increase of the percentage of seed germination, the mechanisms inferred are deinhibition and scarification.

b) Intact fruits (F): mature fruits collected from at least 10 individuals of each plant species and stored in paper bags until the beginning of the germination experiment. The dehydration process that fruits suffer inside the paper bags simulates what would happen with those nondispersed fruits, i.e., fruits that fall on the ground. Since $L$. cestroides is the only species with more than one seed per fruit, the percentage of seed germination was calculated by adding the germinated seeds plus the number of un-germinated seeds within intact fruits opened at the end of the experiment to get a total seed count per fruit.

c) Manually extracted seeds (M): seeds were manually removed from mature fruits, and any pulp remaining on the seed coat was washed off. This condition allows knowing whether the seeds are subject to an inhibitory mechanism produced by the pulp. For Z. coco, the seeds were left in water for one day to facilitate the extraction of the oily blackish mesocarp that is firmly attached to the seed. The great majority of the oily mesocarp was extracted using tweezers.

Each replicate, for each treatment, consisted of a group of seeds or fruits from only one species placed in a transparent plastic container of $5 \mathrm{~cm}$ height, $8 \mathrm{~cm}$ diameter $\left(250 \mathrm{~cm}^{3}\right)$ (Table 2). For the "intact fruit" and "manually extracted seeds" treatments, we used mature fruits collected from the same individual plant or seed trap. The number of seeds per replicate and replicates per treatment varied among plant species and were determined according to the average number of seeds found in the faecal or regurgitated samples (Table 2). Seed sources and replicates for the three germination treatments are shown in Table 2.

Germination experiments were carried out in a germination chamber. Each replicate was placed in a transparent plastic container, covered with holes for ventilation, containing 1 centimetre of sterilized soil mixed with sand. The plastic containers were kept in a germination chamber at $25^{\circ} \mathrm{C}$ with 14 hours of light. Seeds or fruits were sown in the substrate and watered regularly. The groups of seeds or fruits were examined for germination (radicle emergence) twice a week. Germinated seeds were counted and removed to reduce interaction with un-germinated seeds and to avoid re-counting. Germination was monitored 
for one year in L. cestroides and Condalia spp. (from August 2009 to August 2010) and for eight months in the remaining plant species (from June 2011 to February 2012). We decided to reduce the time of the second germination experiment because we did not record seed germination after eight months in the first experiment.

\section{Statistical analyses}

We calculated the number and percentage of germinated seeds for each treatment at the end of the experiment for the seven plant species selected. The percentage of seed germination was analyzed with a generalized linear model with a binomial error structure and logit link function, using the seed treatments as fixed factor (three levels: gut-passed seeds, manually extracted seeds and intact fruits). A quasi-binomial error structure was used due to over-dispersion in the response variables in many species (see Table 3). When differences among treatments were significant, "Di Rienzo, Guzmán and Casanoves" (DCG) a posteriori test was performed. The GLMs were performed in Infostat (Di Rienzo et al. 2013) and its interface to $\mathrm{R}$ ( $\mathrm{R}$ 2.15.0, $\mathrm{R}$ development core team 2012). As an estimate of germination speed, we used the Survival Analysis module of Kaplan-Meier available in SPPS 10 to compare cumulative germination percentages among treatments. We used log-rank tests (Mantel-Cox), a non-parametric test recommended for evaluating the effect of categorical predictive variables. In all cases, $\mathrm{p} \leq 0.05$ was considered to assess significant differences among treatments (Traveset et al. 2008).

\section{Results}

Germinability

There were significant treatment effects on germination percentage for all species (Table 3, Fig 2). In general, there was a reduced likelihood of seed germination in intact fruits, ranging from 4 to $22 \%$, however C. ehrenbergiana presented an average germination percentage higher than 50\%. Germination of gut-passed seeds varied from 17 to $74 \%$ and from 8 to $73 \%$ for manually extracted seeds.

Gut-passed seeds showed significantly higher germination percentages than intact fruits in all the species with the exception of S. fasciculatus (Fig. 2F). In S. fasciculatus, the 
germination of manually extracted seeds was significantly higher than gut-passed seeds and intact fruits. C. ehrenbergiana, L. camara, L. molleoides, Z. coco gut passed seeds showed significantly higher values than manually extracted seeds (Fig. 2 A,C,D,G). From these four species only in L. camara manually extracted seeds also differed from intact fruits (Fig. 2C). In L. cestroides and Condalia spp. manually extracted seeds differed from intact fruits, but not with gut passed seeds (Fig. 2 B, E).

\section{Germination speed}

There were large treatment effects on the speed at which seeds germinated (Table 4, Fig. 3). Overall, the cumulative germination of gut-passed seeds differed significantly from manually extracted ones, being faster in C. ehrenbergiana, L. camara, L. molleoides and $Z$. coco (Fig. 3A, C, D and G) and slower in Condalia spp., L. cestroides and S. fasciculatus (Fig. 3B, E and F). Gut-passed seeds also germinated significantly faster than those of intact fruits, but in Condalia spp. and $S$. fasciculatus the differences were not significant (Fig. 3B and 3F). Manually extracted seeds germinated significantly faster than those of intact fruits for all species, excepted for Z. coco, in which the difference was not significant (Fig. 3G).

\section{Discussion}

Frugivorous birds are key agents for the maintenance and expansion of many plant species, because they disperse the plant's seeds and may facilitate their germination. In this study we analyzed germination percentage and speed of germination in seven species of the Chaco Serrano Forest of Córdoba, Argentina, in order to disentangle if birds are having a positive, a negative or a neutral effect on seed germination. In addition, as proposed by Samuels and Levey (2005) we aimed to understand through which mechanisms this interaction is occurring. For most of the plant species in this study (six out of seven), the action of frugivorous birds facilitated seed germination, either through scarification $(C$. ehrenbergiana, L. molleoides and Z. coco), deinhibition (Condalia spp. and L. cestroides ) or through combined mechanisms (L. camara). 
In C. ehrenbergiana, L. molleoides and Z. coco there were significantly higher percentage of seed germination and speed of germination in gut-passed seeds compared to manually extracted seeds, which is indicative of a scarification effect. Therefore, these species must have a double dependency on birds -i.e., for dispersal and germination. It is possible that in C. ehrenbergiana and L. molleoides also a deinhibition effect exists which was only detected in their speed of germination. It is important to highlight that the seeds of C. ehrenbergiana germinated successfully more than $50 \%$ even in intact fruits. In addition, Renison et al. (2011) found that seeds of this species when ingested by Rhea americana had lower germination than those of intact fruits and suggested that C. ehrenbergiana seeds could be adapted to dispersal by small bird species with shorter gut retention times, which is supported by our results. In Z. coco since pulp removal of this species is difficult (probably not fully removed in our manually extracted treatment), we cannot discard a deinhibition effect. However, in another congeneric species, Z. dissitum, Ying-Zi et al. (2009) observed higher germination after seeds were scarified with sulfuric acid. Therefore, our results and those in Z. dissitum suggested that scarification is the main mechanisms in this genus.

In Condalia spp. and L. cestroides higher germination percentages in manually extracted seeds and gut passage seeds than those from intact fruits were observed suggesting that the seeds increased their germinability by a deinhibition effect (Traveset 1998; Traveset and Verdú 2002; Robertson et al. 2006; Traveset et al. 2007). The speed of germination also suggested this pattern even though it does not fully supportit, in both species the speed of seed germination of extracted seeds was significantly greater than for that from seeds residing in intact fruit, but germination speed of extracted seeds was also faster than that for gut passed seeds.

Therefore, in L. cestroides the speed results suggested that birds, even though they provide a deinhibition, they are not capable of promoting the greatest germination velocity possible for the species. In Condalia spp., gut passed seeds showed similar speed than intact fruits, thus birds seem not to exert any benefit in the speed of germination, deinhibition may be acting only in the germinability of this species. For Condalia spp. Renison et al. (2010) also found that seed germination was higher in manually extracted seeds of Condalia 
microphylla in relation to intact fruits, but seeds ingested by $R$. americana showed lower germination percentages. Altogether, the comparison of our results and the previous work of Renison et al. (2010) for C. ehrenbergiana and Condalia spp. suggest that different bird species may exert different effects on seed germination and that the different plant species also respond differently to gut passage. In addition, performing experiments that will consider the different Condalia species coexisting in the study area $(C$. buxifolia, $C$. microphylla and C. montana) would be important for assessing the array of interactions between these plant species and their seed dispersers.

Only in L. camara do birds seem to exert both mechanisms, because statistically significant differences were observed between gut passage seeds and manually extracted seeds and between the latter and seeds from intact fruits in both of the variables analyzed. Thus, birds are highly important for seed germination of this species which is considered a native invasive species because it is originally from other phytogeographic regions of the country (Giorgis and Tecco 2014). Therefore, these results are important if they are intended to develop some management strategy in this species.

Finally, in S. fasciculatus, the fruit pulp is firmly attached to the seed, making pulp removal by abrasion in bird guts possibly difficult, which might explain the higher germination and speed in manually extracted seeds in relation to gut-passed ones. The low values obtained in gut passed seeds suggested that in this species birds might be exerting a negative effect on seed germination. It is possible that other bird species or other terrestrial dispersers, may be involved in pulp removal of $S$. fasciculatus fruits producing different results. A deinhibition mechanism was observed in other congeneric species $(S$. Terebinthifolius) from Argentina, Paraguay and Brazil (Panetta and Mckee 1997; D’Avila et al. 2010).

Our detailed sampling effort to obtain defecated seeds contributes to better understand the role that the community of frugivorous birds exerts on the seed germination of native plant species in the Chaco Serrano Woodland. In addition, except for S. fasciculatus most species of the Chaco Serrano region depend on birds for their dispersal and germination, therefore birds facilitated the maintenance of their populations in this region. However, it 
would be ideal to repeat these experiments in field conditions because it is possible that even though we did not use Petri dishes, the relatively small volume of soil used in each container within the experimental chambers may have been insufficient to allow inhibitors to leach away and may have altered the micro-organisms available for descomposition, modifying the pulp breakdown as it would occur naturally in the soil (Robertson et al. 2006). These alterations may have exacerbated the inhibitors effects observed here in intact fruits.

Finally it is important to clarify that a faster germination could have either negative or positive consequences for plant populations, depending on climatic conditions of the area at the time when seeds germinate. The environmental conditions in the Chaco Serrano Woodland are very different in the wet and dry seasons (Torres and Galetto 2011). The species reported here are dispersed during the wet season (Díaz Vélez 2013). Therefore, a faster germination may be advantageous for these species, because it would ensure seedling establishment during the wet period, as also occurs in other regions with pronounced seasonality, such as some temperate and desert areas (Traveset 1998). However, the exact consequences of different germination speeds for Chaco Serrano Woodland species requires further study. Germination speed is a complex variable and the advantages or disadvantages for each plant species may be influenced by the action of granivores and herbivores, as well as fluctuations in resource availability during seedling establishment (Daws et al. 2002; Yirdaw and Leinonen 2002). Also, it has been suggested that variability in germination speed add temporal heterogeneity to seed germination responses, which may favour species establishment and regeneration (Izhaki and Safriel 1990; Reid and Armesto 2010).

\section{Concluding remarks}

Despite the effects of frugivorous birds on seed germination, it is essential to establish the regeneration possibilities for the bird-dispersed plant species (Baskin and Baskin 1998), which remain unknown for many ecosystems from Argentina and South America (Reid and Armesto 2011). Since our study considers seed dispersal of common plant species by the most abundant bird dispersers of the area (Ponce et al. 2012; Díaz Vélez 2013), we provide a broad view of the impact of bird species on these woody species. Frugivorous birds not only move seeds to different microsites, but also provide different treatments to the seeds, 
enhancing the chances of seed germination and plant establishment in the Chaco Serrano Woodland (Díaz Vélez 2013).

\section{Acknowledgments}

We thank Leonardo Ontivero, Lourdes Boero and Martín Lepez for assistance in the field work, and Julia Galetto for English advice. We thank Estancia Santo Domingo for their continuous support during field work. This research was supported by the Consejo Nacional de Investigaciones Científicas y Técnicas (CONICET), Secretaría de Investigaciones Científicas y Tecnológicas (Universidad Nacional de Córdoba) and Agencia Nacional de Promoción Científica y Tecnológica (FONCyT). MCDV is a CONICET fellowship holder, AEF and LG are CONICET researchers, WS is professor and researcher at UNICAMP.

\section{References}

Aide, T. M., Clark, M. L., Grau, H. R., López-Carr, D., Levy, M.A., Redo, D., BonillaMoheno, M., Riner, G., Andrade-Núñez, M. J., and Muñiz, M. 2012. Deforestation and Reforestation of Latin America and the Caribbean (2001 - 2010). Biotropica 45 (2): 262-271. doi: 10.1111/j.1744-7429.2012.00908.x

Ashworth, L., and Martí, M.L. 2011. Forest fragmentation and seed germination of native species from the Chaco Serrano Forest. Biotropica 43 (2): 496-503. doi: $10.1111 / \mathrm{j} .1744-7429.2010 .00721 . \mathrm{x}$

Barnea, A., Yom-Tov, Y. and Friedman, J. 1991. Does ingestion by birds affect seed germination?. Funct. Ecol. 5: 394-402.

Baskin, C. C., and Baskin, J. M. 1998. Seeds: ecology, biogeography, and evolution of dormancy and germination. Academic Press, San Diego. 
Cagnolo, L., Cabido, M., and Valladares, G. 2006. Plant species richness in the Chaco Serrano Woodland from central Argentina: Ecological traits and habitat fragmentation effects. Biol. Conserv. 132 (4): 510-519. doi: 10.1016/j.biocon.2006.05.012

Capitanelli, R. G. 1979. Clima. In: Geografía física de Córdoba. Edited by J. B. Vázquez, R. A. Miatello and M. E. Roqué. Editorial Boldt, Buenos Aires. pp. 45-138.

Cipollini, M. L., and Levey, D. J. 1997. Secondary metabolites of fleshy vertebrate-dispersed fruits: adaptive hypotheses and implications for seed dispersal. Am. Nat. 150: 346-372.

Daws, D. I., Burslem, R. P., Crabtree, L. M., Kirkman, P., Mullins, C. E., and Dalling, J. W. 2002. Differences in seed germination responses may promote coexistence of four sympatric piper species. Funct. Ecol. 16(2): 258-267. doi: 10.1046/j.13652435.2002.00615.x

D’Avila, G., Gomes-Jr, A., Canary, A. C. and Bugoni, L. 2010. The role of avian frugivores on germination and potential seed dispersal of the Brazilian Pepper Schinus terebinthifolius [online]. Biota Neotropica 10 (3): 45-51.

http://dx.doi.org/10.1590/S1676-06032010000300004.

Díaz Vélez, M. C. 2013. Evaluación de la dispersión de semillas por aves de plantas nativas en un paisaje fragmentado del bosque chaqueño de Córdoba. Ph D thesis, National University of Córdoba, Córdoba, Argentina.

Di Rienzo, J. A., Casanoves, F., Balzarini, M. G., Gonzalez, L., Tablada, M., Robledo, C. W. 2013. InfoStat version 2013. Grupo InfoStat, FCA, Universidad Nacional de Córdoba, Argentina. 
Funes, G. F., Díaz, S. and Venier, P. 2009. La temperatura como principal determinante de la germinación en especies del Chaco seco de Argentina. Ecologia Austral 19(2): 129-138.

Galetto, L., Aguilar, R., Musicante, M., Astegiano, J., Ferreras, A., Jausoro, M., Torres, C., Ashworth, L., Eynard, C. 2007. Fragmentación de hábitat, riqueza de polinizadores, polinización y reproducción de plantas nativas en el Bosque Chaqueño de Córdoba, Argentina. Ecología Austral 17: 67-80.

Gavier, G. I., and Bucher, E. H. 2004. Deforestación de las sierras chicas de córdoba (argentina) en el período 1970-1997. Academia Nacional de Ciencias 101: 1-28.

Giorgis, M. A., Cingolani, A. M., Chiarini, F., Chiapella, J., Barboza, G., Ariza Espinar, L., Morero, R., Gurvich, D. E., Tecco, P. A., Subils, R., and Cabido M. 2011. Composición florística del Bosque Chaqueño Serrano de la Provincia de Córdoba, Argentina. Kurtziana 36 (1): 9-43.

Giorgis, M., and Tecco, P. A. 2014. Arboles y arbustos invasores de la Provincia de Córdoba (Argentina): una contribución a la sistematización de bases de datos globales. Boletín de la Sociedad Argentina de Botánica 49(4): 681-603.

Grilli, G., and Galetto, L. 2009. Remoción de frutos de una especie invasora (Lantana camara L.) en el Bosque Chaqueño de Córdoba (Argentina). Ecología Austral 19(2): 149-156.

Izhaki, I., and Safriel, U. N. 1990. The effect of some Mediterranean scrubland frugivores upon germination patterns. J. Ecol. 78: 56-65. 
Lehouck, V., Spanhove ,T., and Lens, L. 2011. Avian fruit ingestion differentially facilitates seed germination of four fleshy-fruited plant species of an Afrotropical forest. Plant Ecol. Evol. 144(1): 96-100. doi: 10.5091/plecevo.2011.503

Luti, R., Bertrán, M., Galera, F.M., Müller de Ferreira , N., Berzal, M., Nores, M., Herrera, M.A., and Barrera, J.C. 1979. Vegetación. In: Geografía física de la Provincia de Córdoba. Edited by: J. B. Vázquez, R. Miatello and M. Roque. Editorial Boldt, Buenos Aires. pp. 268-297.

Moglia, G., and Gimenez, A. M. 1998. Rasgos anatómicos característicos del hidrosistema de las principales especies arboreas de la región Chaqueña Argentina. Invest. Agra.: Sist. Recur. For. 7: 41-53.

Panetta, F. D., and Mckee, J. 1997. Recruitment of the invasive ornamental, Schinus terebinthifolius, is dependent upon frugivores. Austral Ecol. 22: 432-438.

Ponce, A. M., Grilli, G., and Galetto L. 2012. Frugivoría y remoción de frutos ornitócoros en fragmentos del bosque chaqueño de Córdoba ( Argentina ). Bosque 33: 33-41.

Reid, S. and Armesto, J. J. 2011. Avian gut-passage effects on seed germination of shrubland species in Mediterranean central Chile. Plant Ecol. 212: 1-10. doi: 10.1007/s11258-0109796-8.

Renison, D., Valladares, G., and Martella, M. B. 2011. The effect of passage through the gut of the Greater Rhea (Rhea americana) on germination of tree seeds: implications for forest restoration. Emu 110(2): 125-131. doi: http://dx.doi.org/10.1071/MU09090 
Robertson, A. W., Trass, A., Ladley, J. J., and Kelly, D. 2006. Assessing the benefits of frugivory for seed germination: the importance of the deinhibition effect. Funct. Ecol. 20: 58-66. doi: 10.1111/j.1365-2435.2005.01057.x.

Samuels, I. A., and Levey, D. J. 2005. Effects of gut passage on seed germination: do experiments answer the questions they ask?. Funct. Ecol. 19(2): 365-368. doi: $10.1111 / j .1365-2435.2005 .00973 . x$

Schupp, E. W., Jordano, P. and, Gómez, J. M. 2010. Seed dispersal effectiveness revisited: a conceptual review. New Phytol. 188(2): 333-353. doi: 10.1111/j.14698137.2010.03402.x.

Torres, C., and Galetto, L. 2011. Flowering phenology of co-occurring Asteraceae: a matter of climate, ecological interactions, plant attributes or of evolutionary relationships among species? Org. Divers. Evol. 11: 9-19. doi: 10.1007/s13127-011-0038-2.

Traveset, A. 1998. Effect of seed passage through vertebrate frugivores' guts on germination: a review. Perspect. Plant Ecol., Evol. Syst. 1: 151-190. doi: 10.1078/1433-8319-00057

Traveset, A., and Verdú, M. 2002. A meta-analysis of the effect of gut treatment on seed germination. In: Seed dispersal and Frugivory: Ecology, Evolution and Conservation. Edited by: D. J. Levey, W. R. Silva and M. Galetti. CAB International, Wallingford, UK. pp. 339-350.

Traveset, A., Robertson, A. W., and Rodríguez-Pérez, J. 2007. A review on the role of endozoochory in seed germination. In: Seed dispersal : Theory and its application in a changing world. Edited by: A. J. Dennis, E. W. Schupp, R. J. Green and D. A. Westcott. CAB international, Oxfordshire, UK. pp 78-103. 
Traveset, A., Rodríguez-Pérez, J., and Pías, B. 2008. Seed trait changes in dispersers' guts and consequences for germination and seedling growth. Ecology 89: 95-106. doi: 10.1890/07-0094.1.

Ying-Zi, M., BoHua, Y., and Ping, W. 2009. Study on seed dormancy mechanism and germination of Zanthoxylum dissitum Hemsl. J. Nat. Sci. of Hunan Normal University 32: 98-102.

Yirdaw, E., and Leinonen, K. 2002. Seed germination responses of four afromontane tree species to red/far-red ratio and temperature. Forest Ecol. Manag.168: 53-61.

Zak, M. R., Cabido, M., and Hodgson , J. G. 2004. Do subtropical seasonal forests in the Gran Chaco, Argentina, have a future?. Biol Conserv 120(4): 589-59. 
Table 1. List of species studied in the Chaco Serrano Woodland in Córdoba, Argentina. Family, common name, growth forms, fruiting periods, fruit traits and frugivorous bird species that consume the fruits.

Plant species

\begin{tabular}{|c|c|c|c|c|c|c|c|}
\hline & $\begin{array}{c}\text { Celtis } \\
\text { ehrenbergiana }\end{array}$ & $\begin{array}{c}\text { Condalia } \\
\text { spp. }^{a}\end{array}$ & $\begin{array}{l}\text { Lantana } \\
\text { camara }\end{array}$ & $\begin{array}{c}\text { Lithraea } \\
\text { molleoides }\end{array}$ & $\begin{array}{c}\text { Lycium } \\
\text { cestroides }\end{array}$ & $\begin{array}{c}\text { Schinus } \\
\text { fasciculatus }\end{array}$ & $\begin{array}{c}\text { Zanthoxylum } \\
\text { coco }\end{array}$ \\
\hline Family & Celtidaceae & Rhamnaceae & Verbenaceae & Anacardiaceae & Solanaceae & Anacardiaceae & Rutaceae \\
\hline $\begin{array}{l}\text { Common } \\
\text { name }\end{array}$ & Tala & Piquillín & $\begin{array}{l}\text { Bandera } \\
\text { española }\end{array}$ & $\begin{array}{l}\text { Molle de } \\
\text { Beber }\end{array}$ & Tumiñico & Moradillo & Coco \\
\hline Growth form & Tree & $\begin{array}{l}\text { Shrub- } \\
\text { small tree }\end{array}$ & Shrub & Tree & $\begin{array}{l}\text { Shrub- } \\
\text { small tree }\end{array}$ & Shrub & Tree \\
\hline $\begin{array}{l}\text { Fruiting } \\
\text { period }^{\text {b }}\end{array}$ & Jan-Aug & Jan-Feb & Jan-May & Jan-Oct & Jan-May & Jan-Aug & Jan-Aug \\
\hline Fruit type $^{c}$ & drupe & drupe & drupe & drupe & berry & drupe & $\begin{array}{l}\text { dehiscent } \\
\text { follicle }\end{array}$ \\
\hline $\begin{array}{c}\text { Fruit } \\
\text { diameter } \\
(\mathrm{mm})\end{array}$ & $6-9$ & 8 & $4-7$ & $6-8$ & $5-6$ & $4-5$ & $5-7$ \\
\hline Fruit colour & yellow-orange & $\begin{array}{c}\text { dark purple- } \\
\text { dark red }\end{array}$ & blue-black & $\begin{array}{c}\text { translucent } \\
\text { with black pulp }\end{array}$ & $\begin{array}{l}\text { dark red- } \\
\text { purple }\end{array}$ & violet-purple & shiny black \\
\hline Bird species $^{d}$ & $\begin{array}{c}\text { Elasp, Pitsul, } \\
\text { Salaur, Thrbon, } \\
\text { Turama }\end{array}$ & $\begin{array}{c}\text { Elasp, Pitsul, } \\
\text { Salaur, Thrbon, } \\
\text { Turama }\end{array}$ & $\begin{array}{l}\text { Elasp, } \\
\text { Turama }\end{array}$ & Colmel & $\begin{array}{l}\text { Elasp, Pitsul, } \\
\text { Poonig, } \\
\text { Salaur, } \\
\text { Thrbon, } \\
\text { Turama }\end{array}$ & $\begin{array}{l}\text { Elasp, Salaur, } \\
\text { Thrbon, } \\
\text { Turama }\end{array}$ & $\begin{array}{l}\text { Elasp, Pitsul, } \\
\text { Salaur, }\end{array}$ \\
\hline
\end{tabular}

${ }^{\mathrm{a}}$ This Includes three species (Condalia montana, C. buxifolia and C. microphylla) difficult to tell apart because their seeds are very similar.

${ }^{\mathrm{b}}$ Data obtained from seed traps located in the forest fragments (DíazVélez 2013).

${ }^{c}$ One seed per fruit in all, except for L. cestroides (29 seeds per fruit in average).

${ }^{\mathrm{d}}$ Data obtained from personal observations in the study area and literature (Ponce et al. 2012, De la Peña 2012, Díaz Vélez 2013): Abbreviations: Colmel: Colaptes melanochloros; Elasp: Elaenia parvirostris and E. albicep; Pitsul: Pitangus sulphuratus; Poonig: Poospiza nigrorufa; Salaur: Saltator aurantiirostris; Thrbon: Thraupis bonariensis; Turama: Turdus amaurochalinus. 
Table 2. Seed sources of bird-dispersed seeds, number of seeds per replicate and number of replicates per treatment.

Plant species

\begin{tabular}{cccccccc}
\cline { 2 - 6 } & $\begin{array}{c}C . \\
\text { ehrenbergiana }\end{array}$ & $\begin{array}{c}\text { Condalia } \\
\text { spp. }\end{array}$ & L. camara & L. molleoides & L. cestroides & S. fasciculatus & Z. coco \\
\hline $\begin{array}{c}\text { Source of } \\
\text { bird-dispersed } \\
\text { seeds }\end{array}$ & traps $^{\mathrm{a}}$ & mist nets $^{\mathrm{b}}$ & traps & traps & mist nets & traps & traps \\
$\begin{array}{c}\text { Number of } \\
\text { seeds per } \\
\text { replicate }\end{array}$ & 16 & 7 & 20 & 10 & 28 & 20 & 16 \\
$\begin{array}{c}\text { Number of } \\
\text { replicates per } \\
\text { treatment }\end{array}$ & 13 & 4 & 5 & 6 & 17 & 7 & 5 \\
\hline
\end{tabular}

${ }^{a}$ Seed traps: a total of 24050 x $50 \mathrm{~cm}$ nylon traps were placed below tree species in eight forest fragments of the Chaco Serrano Woodland during 6 months (January to June, 2011).

${ }^{\mathrm{b}}$ Mist nets: Nets (12 m x $2.6 \mathrm{~m}, 36 \mathrm{~mm}$ mesh size) were placed in different locations in eight forest fragments (total 1023 net hours) during the fruit peak of bird-dispersed plants (January to April, 2009). We placed a plastic sheet beneath each deployed net in order to collect the faecal samples as birds upon being caught might drop them. Also, we held captured birds in cloth bags for no more than 20 minutes to collect faecal samples. 
Table 3. Degrees of freedom (df) and $\mathrm{p}$ values for the GLM performed for each plant species comparing intact fruit, manually extract seeds and gut-passed seeds.

\begin{tabular}{|c|c|c|}
\hline Plant species & $\mathrm{df}$ & $\mathrm{P}$ value \\
\hline C. ehrenbergiana ${ }^{*}$ & 2 & 0.05 \\
\hline Condalia spp. ${ }^{*}$ & 2 & 0.03 \\
\hline L. camara* & 2 & $<0.0001$ \\
\hline L. molleoides & 2 & $<0.0001$ \\
\hline L. cestroides ${ }^{*}$ & 2 & $<0.0001$ \\
\hline S. fasciculatus ${ }^{*}$ & 2 & $<0.0001$ \\
\hline Z. coco & 2 & $<0.0001$ \\
\hline
\end{tabular}

Species that were analysed with a quasi-binomial error structure due to over-dispersion 
Table 4. Chi squared values $\left(\mathrm{X}^{2}\right)$ and $\mathrm{p}$ values for the Log-rank tests (Mantel-Cox) performed for each plant species comparing intact fruit (F), manually extract seeds $(\mathrm{M})$ and gut-passed seeds $(\mathrm{G})$.

Pairwise comparisons

\begin{tabular}{lcccccc} 
& \multicolumn{2}{c}{ Fvs G } & \multicolumn{2}{c}{ F vs M } & \multicolumn{2}{c}{ G vs M } \\
\hline Plant species & $\mathrm{X}^{2}$ & $\mathrm{P}$ value & $\mathrm{X}^{2}$ & $\mathrm{P}$ value & $\mathrm{X}^{2}$ & P value \\
\hline C. ehrenbergiana & 56.243 & $<0.0001$ & 5.106 & 0.024 & 33.703 & $<0.0001$ \\
Condalia spp. & 3.451 & 0.063 & 12.07 & 0.001 & 4.003 & 0.045 \\
L. camara & 50.469 & $<0.0001$ & 16.950 & $<0.0001$ & 11.955 & 0.001 \\
L. molleoides & 24.007 & $<0.0001$ & 4.27 & 0.039 & 5.757 & 0.016 \\
L. cestroides & 130.102 & $<0.0001$ & 168.646 & $<0.0001$ & 3.944 & 0.047 \\
S. fasciculatus & 0.181 & 0.67 & 85.855 & $<0.0001$ & 76.59 & $<0.0001$ \\
Z. coco & 34.956 & $<0.0001$ & 1.684 & 0.194 & 26.341 & $<0.0001$ \\
\hline
\end{tabular}


Fig. 1. Experimental identification of mechanisms related to the increase of seed germination and acting (or not) on bird gut-passed seeds following the scheme proposed by Samuels and Levey (2005). G: "Gut-passed seeds", F: “Intact fruits", M: “Manually extracted seeds"

Fig. 2. Proportion of germination for each seed treatment: G: "Gut-passed seeds", F: "Intact fruits", M: "Manually extracted seeds"; for (A) C. erhenbergiana, (B) Condalia spp., (C) L. camara, (D) L. molleoides, (E) L. cestroides, (F) S. fasciculatus, and (G) Z. coco. Different letters indicate significant differences, $P \leq 0.05$.

Fig. 3. Cumulative seed germination percentages for each seed treatment: G: "Gut-passed seeds", F: "Intact fruits", M: "Manually extracted seeds"; for (A) C. ehrenbergiana, (B) Condalia spp., (C) L. camara, (D) L. molleoides, (E) L. cestroides, (F) S. fasciculatus, and (G) Z. coco. Different letters indicate significant differences, $P \leq 0.05$. 


\section{$G>M>F \quad$ Scarification + Deinhibition effect \\ $G=M>F \quad$ Deinhibition effect \\ $G>M=F \quad$ Scarification effect \\ $G=M=F \quad$ Neutral effect}

Fig. 1. Experimental identification of mechanisms related to the increase of seed germination and acting (or not) on bird gut-passed seeds following the scheme proposed by Samuels and Levey (2005). G: "Gutpassed seeds", F: "Intact fruits", M: "Manually extracted seeds"

Fig. 1 
A) Celtis ehrenbergiana

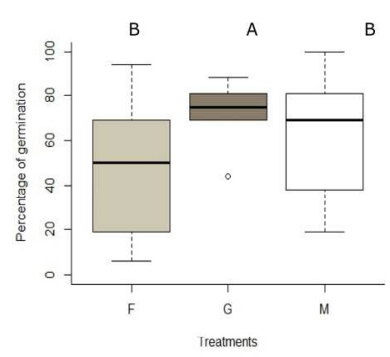

D) Lithraea molleoides
B) Condalia spp.

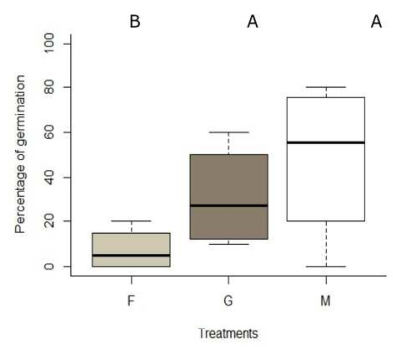

E) Lycium cestroides

C) Lantana camara

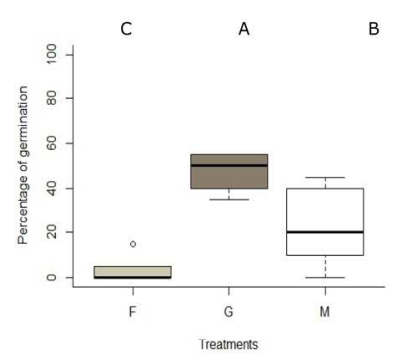

F) Schinus fasciculatus

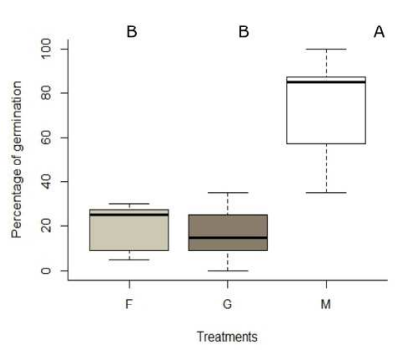

G) Zanthoxyllum coco

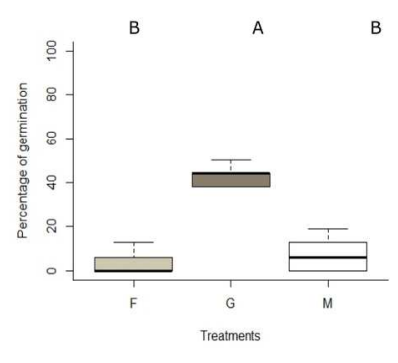

Fig. 2. Proportion of germination for each seed treatment: G: "Gut-passed seeds", F: "Intact fruits", M: "Manually extracted seeds"; for (A) C. erhenbergiana, (B) Condalia spp., (C) L. camara, (D) L. molleoides, (E) L. cestroides, (F) S. fasciculatus, and (G) Z. coco. Different letters indicate significant differences, $P$ $\leq 0.05$.

Fig. 2

$224 \times 238 \mathrm{~mm}(300 \times 300 \mathrm{DPI})$ 
A) Celtis ehrenbergiana

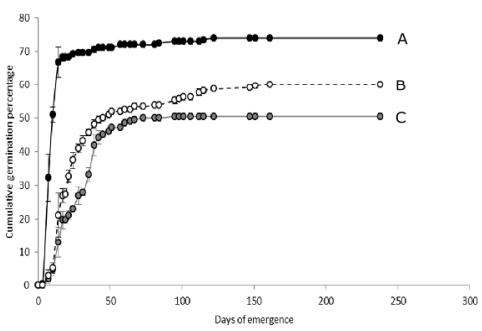

C) Lantana camara

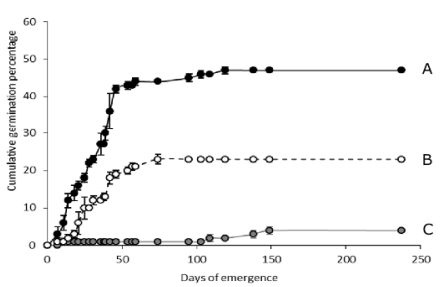

E) Lycium cestroides

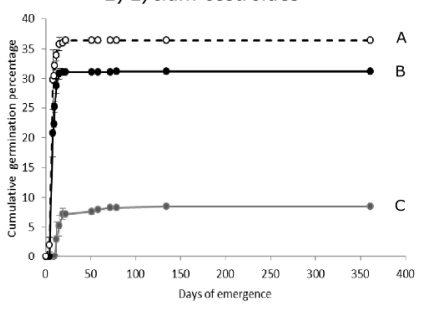

G) Zanthoxyllum coco

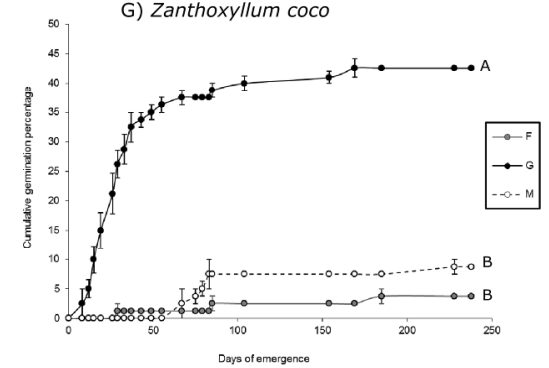

B) Condalia spp.

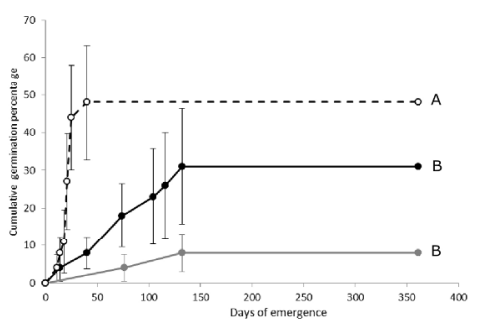

D) Lithraea molleoides

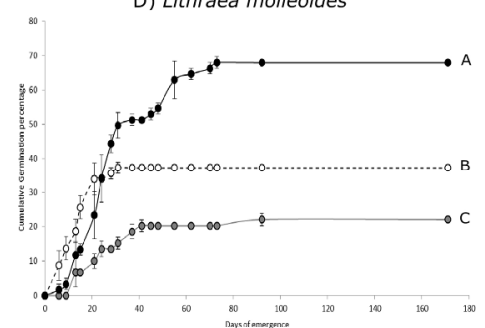

F) Schinus fasciculatus

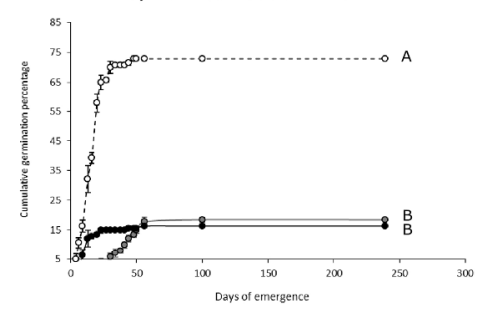

Fig. 3. Cumulative seed germination percentages for each seed treatment: G: "Gut-passed seeds", F: "Intact fruits", M: "Manually extracted seeds"; for (A) C. ehrenbergiana, (B) Condalia spp., (C) L. camara, (D) L. molleoides, (E) L. cestroides, (F) S. fasciculatus, and (G) Z. coco. Different letters indicate significant differences, $\mathrm{P} \leq 0.05$.

Fig. 3

$292 \times 413 \mathrm{~mm}(300 \times 300$ DPI $)$ 